\title{
'ONCE YOU GET THE CARD YOU CAN DO ANYTHING YOU WANT'. MIGRANT IDENTITIES AND GENDER TRANSGRESSION IN CHICANA DRAMATIC LITERATURE ${ }^{* 1}$
}

\author{
Marta Fernández Morales*
}

\begin{abstract}
Issues of migration, frontiers and identity are recurrent in Chicano/a literature. In Real Women Have Curves the protagonists are conditioned by la migra as much as by race stereotyping and gender limits, living in a metaphoric frontera between clandestine existence and public acknowledgement; between curvy, dark-skinned beauty, and white, androgynous images of womanly perfection. The Hungry Woman is situated in a symbolic territory where Medea has been banished for being a lesbian. Both texts are constructed around ethnic and gender identities, and they both create worlds in which limits are broken and barriers transgressed with a clear Chicana feminist conscience.
\end{abstract}

Key Words: migration, (ethnic, gender and sexual) identity, transgression, frontier

Resumen: Temas como migración, fronteras e identidad proliferan en la literatura chicana. En Real Women Have Curves las protagonistas están condicionadas por "la migra", estereotipos de raza y límites de género, viviendo en una "frontera" entre la clandestinidad y el reconocimiento; entre una belleza oscura con curvas e imágenes de perfección blancas y andróginas. The Hungry Woman se sitúa en una "tierra de nadie" a donde Medea es desterrada por lesbiana. Ambos textos crecen alrededor de la identidad étnica y de género, y ambos crean mundos en los que se rompen barreras y se transgreden límites con una clara conciencia feminista.

Palabras clave: migración, identidad (étnica, de género y sexual), transgresión, frontera

For the past four centuries, Mexican women have moved north to work in the United States of America. The beginning of the flow of migrants was marked by the Coronado expedition of 1540 (Ruiz 2000: 1), and ever since then, mexicanas have planted their roots in the land of the gringos, keeping their connections to their original culture through

\footnotetext{
Fecha de recepción: abril 2005

Fecha de aceptación y versión final: mayo 2005

** Profesora del Departamento de Filología Española, Moderna y Latina, Universitat de les Illes Balears; $\bowtie$ marta.fernandez@uib.es.

${ }^{1}$ This article has been researched and written within the framework of the research group "L'expressió de la diversitat en el món anglòfon", at the UIB. I would like to thank my colleagues in the group for the constant exchange of opinions and experiences, as well as for the rigor and passion they put into their work, which allows me to learn from them everyday.
} 
spirituality, storytelling, cooking, and other forms of popular culture. The struggle initiated by the immigrants to preserve their ancestral cultural elements while integrating themselves in a new context gave rise to the Chicano/a Movement, which over time has developed its own distinct manifestations. In politics, chicanismo has dealt with issues of legal/illegal employment and immigration, representation, respect for language and heritage, etc. In the field of artistic work, it has expressed the plight of a community struggling to reconstruct a fragmented history and developing strategies to resist the cultural invasion of the oppressive majorities in a globalized world (Perles Rochel 2004: 11).

Mexican-American women have tried to find their voice inside the movement, facing the conflict of a double militancy that brings together issues of ethnicity and gender: "What resulted was a bitter division between Chicanas and Chicanos. A split also came between traditional, male-identified Chicanas, who refuse to recognize women's struggles as legitimate arenas of dispute, and feminist Chicanas, who insisted on liberation from oppressive cultural traditions" (Saldívar-Hull 2000: 30). Chicana feminism, then, "is inseparable from the historical experience of Chicanos in [the US] since 1848, an experience marked by economic exploitation as a class and systematic racial, social and linguistic discrimination designed to keep Chicanos at the bottom as a reserve pool of cheap labor" (Yarbro-Bejarano 1996: 213).

This article will start off from a brief commentary on the way the Chicano/a movement has dealt with issues of migration, frontiers and gender constrictions, to then try and explore how these topics have been translated into Chicana feminist literature and, in particular, into two plays written by Chicana authors at the end of the twentieth century: Real Women Have Curves and The Hungry Woman.

\section{TAKING MEXICANNESS ACROSS THE BORDERS: CHICANA IMMIGRANTS AND GENDER}

Latinos/as and, in particular, Chicanos/as, form the fastest growing minority in the United States. Their relevance in terms of population and political activity has increased in such a way that the media have started talking about el poder latino. In an article about the North American presidential election in a Spanish journal, for example, the writer emphasized how the influence of the Latino/a community is clearly felt in the U.S. He called this nation a "sponge" that is capable of absorbing different ways of seeing, eating, dressing, etc. (Calvo 2004: 41). However, he also pointed out that Latinos/as are "americanized" in return ${ }^{2}$. A Chicano interviewed by the journalist explains that "[s]er mexicano aquí es otro tipo de mexicanidad. Se puede ser las dos cosas, mexicano y norteamericano, hispano y americano" (qtd. in Calvo 2004: 41).

Trying to preserve their mexicanidad was one of the main preoccupations of a wave of Chicana migrants that lived in the U.S. during the 1980s and 90s. These are the decades in which both López and Moraga elaborated and/or produced the works we are going to analyze in this article; and this is also a relevant moment for policies of Latina migration

\footnotetext{
${ }^{2}$ Although Mexico and other Latin American countries are, obviously, part of America, too, the use of the expression "americanizarse" in the Spanish journal shows how, with time, for many Europeans "America" has come to be identified with the United States.
} 
and citizenship. In the 1980s, gender started to be considered as a criterion to study the flow of migrants, and the statistics revealed that "in contrast to Anglo women, Latinas are growing poorer, working at low-status, low paying jobs, continuing to suffer from low education attainment, and having few opportunities for a better life" ("Latina Policy" 2004: 1). Apparently, the Mexico-U.S. frontier was not the only one that these women needed to leave behind; there were hidden barriers keeping them back even inside the United States.

Apart from the institutional obstacles that the women immigrants were coming across upon arrival, something else was hindering their development as individuals and citizens. Their families had until then been embedded in an ancestral culture loaded with male chauvinist principles and discriminatory practices against women. Struggling to gain equality as workers in their positions in factories, country labor and other (generally) unqualified jobs, the migrant women also had to face Chicanos and their machismo, developed and preserved for centuries through the very respectable institution of la familia.

The traditional Mexican and Mexican-American family has been revealed by Chicana feminists as one of the main tools of gender oppression. Presented by Chicanos as the key to cultural preservation and as the most important axis for the construction of a powerful community in the new gringo context, la familia has forced women into a position of inferiority defined specifically by gender identity. Cherríe Moraga has criticized this practice: "The family, then, becomes all the more ardently protected by oppressed peoples, and the sanctity of this institution is infused like blood into the veins of the Chicano. At all costs, la familia ${ }^{3}$ must be preserved" (1983: 110); and she has added the gender dimension by saying: "We believe the more severely we protect the sex roles within the family, the stronger we will be as a unit in opposition to the Anglo threat" (1983: 110).

Inside the traditional Mexican family, two main things are asked from women, which can be understood as just as many cultural frontiers that need trespassing on the part of Chicanas on their way towards equality: 1) that they stay loyal to their men and their culture, becoming the guardians of tradition and spirituality against the Anglo invasion (after the model of la Virgen de Guadalupe, the quintessence of perfect womanhood); and 2 ) that they respect the traditional gender roles and division of labor (men as breadwinners; women as wives and mothers) in a context of compulsory heterosexuality. For some, like barren Pancha in Real Women Have Curves, the first requirement will be impossible to fulfil; for others like lesbian Medea in The Hungry Woman, deviation from the norm in sexual practice will become a guarantee of ostracism.

In this context, Chicanas at the end of the twentieth century had to devise strategies of subversion of the traditional gender roles. Looking back to their female ancestors, they rediscovered, for example, the value of the women's networks, and they started to build an alternative "herstory" of sisterhood and solidarity in the midst of the struggle for racial and economic equity of the Chicano movement. Already in the earliest migrant movements, "women's networks based on ties of blood and fictive kinship proved central to the

${ }^{3}$ I will use italics for Spanish terms in my essay, except when it is specifically avoided by the author(s) quoted, as is the case here with Cherríe Moraga. 
settlement" (Ruiz 2000: 1); in the 1980s and 90s, just as today, "Chicana feminism as a political movement depends on the love of Chicanas for themselves and each other as Chicanas" (Yarbro Bejarano 1996: 214).

Translated into literature, this movement of preservation of a Chicana identity with new conditions of gender balance has taken the shape of committed, highly personal essays, such as Loving in the War Years by Cherríe Moraga; profoundly autobiographical narratives like Sandra Cisneros' Caramelo, or Canícula, by Norma Elia Cantú; self-reflective poems in the line of Gloria Anzaldúa's or Cordelia Candelaria's; and complex, rich, sometimes very experimental plays that have been put on stage (The Hungry Woman) and even made into popular films, as is the case of López's Real Women Have Curves.

\section{PUTTING THEIR PLIGHT ON STAGE: CHICANA PLAYTEXTS AGAINST REAL AND SYMBOLIC FRONTIERS}

Doubly oppressed, Chicana writers have been pushing from the margins of the canon of American literature for years. Their path has been one of fighting, self-consciousness, vindication and solidarity; but above all, it has been a process of un-learning and relearning some of the political and artistic principles of narrative, poetry or drama. They have struggled with the mestizas inside them and the white, androcentric rules outside them, in order to recover the voice of a community that could have simply faded away and disappeared inside the melting pot of the U.S., had they not been there to prevent it. Cherríe Moraga, Josefina López and others realized they had a mission to fulfil in the benefit of their culture, their sisters and the future of the coming generations. Their literature is a battle against oblivion, because " $[\mathrm{t}]$ he failure to remember, failure to respect and defend the memory carriers, destroys cultures, ecological environments, destroys lives" (Moraga, qtd. in Oliver-Rotger 2004: 8).

The issues raised in Chicana texts are parallel to those addressed in Chicana feminism in general. Politics, identity, and literature are closely linked: "The exclusion of Chicanas from literary authority is intimately linked to the exclusion of Chicanas from other kinds of power monopolized by privileged white males. Their struggle to appropriate the 'I' of literary discourse relates to their struggle for empowerment in the economic, social and political spheres" (Yarbro-Bejarano 1996: 213). They produce literary material more often than not in a highly experimental style, fusing the elements from the different traditions they embody. Chicana writings are textos mestizos, "crazy quilts" of creativity and vindication dealing with frontiers, ethnic and gender limitations, concepts of motherhood and family, sexuality, spirituality, mythology, language, migration, etc.

$$
* *
$$

It is precisely la migra that represents the main threat for the protagonists of Josefina López's comedy Real Women Have Curves, a play that transgresses the frontiers defined by gender roles and the traditional division of labor, offering an alternative idea of Chicana family based on sisterhood and workplace solidarity. A text that also breaks the barriers 
of standard white, Anglo beauty and Mexican female decorum by showing big, dark, selfloving bodies on stage. A dramatic proposal that challenges the rules of language by systematically using Spanglish as a means of communication. A literary manifestation that, above all, situates women as subjects in the center of the action, moving towards a redefinition of Chicana womanhood and following the line of work that López continued with titles like Simply María, or the American Dream (1996), Confessions of Women from East L.A. (1997). Unconquered Spirits: A Historical Play (1997), and Yes! You Too Can Be a Chingona (Narbona Carrión 2004: 225).

Real Women deals with the story of a group of Chicana workers in East Los Angeles, and it is based on the author's personal experience. In the "Playwright's Note", López explains how, while she was living as an illegal immigrant in L.A., where she toiled for five months at her sister's sewing factory, she had the terrifying experience of crossing la migra in the streets: "I quickly turned to my friend and tried to 'act white'. I spoke in English and talked about Jordache jeans and Barbie dolls hoping no one would suspect us" (1996: 5)4. Similarly, her characters live with a constant fear of the immigration agents, even though some of them are already legal citizens by the time the action takes place. In Act One, Scene One, for example, they see a van outside the factory, and they immediately "scatter and hide waiting to be discovered" (López 1996: 14).

A quick look at Josefina López's dramatic career reveals that fear of the U.S. authorities is not only present in Real Women. On the contrary, it has become a recurrent subject matter along the years: "The threat of deportation would inform several of her plays, becoming a kind of leitmotif in the lives of her characters. According to López, she 'became a Chicana' at the age of twenty, ostensibly when she no longer feared deportation" (Huerta 2000: 123). In the play at hand, the issue is dealt with in an ironic way designed to provoke the both the reflection and the smile of a potential audience. In Act One, we are witnesses to Estela's "tragic" confession. Having affirmed that she will not apply for the green card again until she is "clean", she is forced to open her heart to the other women in the factory:

CARMEN: Estela, what did you do?

PANCHA: ¿Qué hiciste?

ESTELA: Well, actually, I did two things.

CARMEN: Two?! ¿Y por qué no me habías dicho? Why is the mother always the last one to know?

ESTELA: Because one is very embarrassing-

CARMEN: ¡A ver dime, condenada! What have you done?

ESTELA: I was arrested for illegal possession of-

ROSALI: Marijuana?!

PANCHA: A gun?!

ESTELA: A lobster (López 1996: 16).

To overcome the fear of la migra and the pressure that their hard work puts of them, López's protagonists build a network of solidarity, humor and sisterhood that takes them

\footnotetext{
${ }^{4}$ Real Women Have Curves had its world première in 1990, but was not published until 1996. The latter is the date I will be using for my bibliographical references in this article.
} 
to final success: Estela meets the deadline of her work, gets her money and is able to get the green card and open her own boutique. On the way, "these women discuss food, abusive relations, male/female interaction, and their own sense of being" (Ramírez 2000: 116). The thread that keeps this highly polyphonic play together is the vision of the events offered by the playwright's alter ego: eighteen-year-old Ana, who wants to go to college and become a writer, ${ }^{5}$ but is forced to work in the factory to help her sister Estela complete an order of dresses for Bloomingdale's: "In this work, Ana pens her thoughts about everyday life throughout the piece; her writing serves as a unifying factor" (Ramírez 2000: 117). She provides the external, most overtly feminist judgement to the situation, initially entering the scene with an air of superiority. However, by the end of the play, she has un-learned some of her preconceived ideas about what it means to be a Chicana worker in the U.S., and has learned about the capacity for transgression, love and resistance of her peers. In her final speech, just before all the characters parade down the theater aisles in their new clothes, she acknowledges:

I always took their work for granted, to be simple and unimportant. I was not proud to be working there at the beginning. [...] But in their subtle ways they taught me about resistance. About a battle no one was fighting for them except themselves. About the loneliness of being women in a country that looks down on us for being mothers and submissive wives. With their work that seems simple and unimportant, they are fighting... Perhaps the greatest thing I learned from them is that women are powerful, especially when working together (López 1996: 69).

In their daily battle for recognition as workers and Chicanas in a hostile environment, the characters in López's play break down several barriers imposed by the various cultures that impregnate them as women immigrants. First of all, they are able to overcome the patriarchal division of labor, becoming breadwinners for their families and active vindicators of their rights of citizenship: "The point of the play is that women can determine for themselves what they will do with their lives and actively take on the charge of resistance to the inequality and oppressive circumstances surrounding them" (Ramírez 2000: 118).

Secondly, they manage to construct an alternative, women-only familia in the factory, showing deep respect, love and sympathy for one another: "The discovery of self and the power of sisterhood reigns strongly in this work" (Ramírez 2000: 118). Thus, they listen to each other's love stories (such as Estelas's suffering for the man she calls her tormento); they support Estela in her way towards the green card by working for free to finish Bloomingdale's order; and they take care of each other in health and spirit (Rosali is criticized for torturing herself with brutal diets; the memories and respect for the ancestors are encouraged).

Finally, the Chicanas in Josefina López's play challenge the limits of the dramatic canon and the theatrical tradition by staging the pride and pleasure of living in plump,

\footnotetext{
${ }^{5}$ In the film adaptation of the play, directed by Patricia Cardoso in 2003, the emphasis moves from the conditions in the workplace towards Ana's desire of an education. The factory is the background to the women's relationships, but it is Ana's war against prejudice and traditional ideas of la familia that best defines the film.
}

Odisea, $n^{\circ}$ 6, ISSN 1578-3820, 2005, 85-96 
well-fed, dark female bodies. Moving away from the typical white, slim, Anglo blonde that usually features as the heroine in the North American stories of success, they come to appreciate their fat, their scars, their birthmarks, and they literally embody liberation from Anglo beauty constrictions by stripping to their underwear on stage (Act Two, Scene Three) and parading in colorful, sexy clothes for big women at the end of the play. Real Women Have Curves "debates and exposes issues of the female body, especially 'fat,' 'large,' 'plump' or voluptuous' bodies, depending upon the gaze of the beholder" (Huerta 2000: 127) ${ }^{6}$, and its protagonists claim for themselves the right to re-define, re-name beauty, friendship and Chicana womanhood in their new home country.

All in all, Josefina López's play represents the humorous vindication of an active role for Chicanas in both Chicano/a and U.S. culture, away from the submissive, chaste, passive model of the Mexican tradition. Through the transgression and destruction of literal and metaphoric barriers established by U.S. institutions and by Chicano patriarchal culture, the protagonist end up achieving a new state of happiness through sisterhood, empowerment and self-love. Aware that plump, dark women like herself were absent from mainstream theater and silenced by conscious neglect from the rulers of the political and cultural elites in America, López, "decided to created her own vehicles to perform” (Huerta 2000: 123). And she gave the establishment a lesson: look around... even in the U.S., las mujeres de verdad tienen curvas!

The Hungry Woman, by L.A. born Chicana playwright Cherríe Moraga, offers a completely different view of life in and beyond the Borderland. Her protagonist ends up alone and pushed to her own death by a system that condemns her for her chicanismo and her sexual option. Expelled from Gringolandia ("white Amerika", in Moraga's words) and not admitted into Aztlán (Chicano territory), Medea is a forced migrant who lives in a no(wo)man's-land called Phoenix, "a city-in-ruin", the dumping site of every kind of poison and person unwanted by its neighbors" (Moraga 2000: 292) ${ }^{7}$. A sexually active, outspoken lesbian and feminist, she has transgressed the frontiers of traditional womanhood and compulsory heterosexuality by living with her lover Luna; she has broken the tradition of taking la Virgen de Guadalupe as a model by praying to pagan goddesses of the Aztec tradition... rejected and humiliated, she finally commits the worst of crimes that can be imputed to a woman: she kills her own son.

As I have stated elsewhere, in this play "Moraga creates a very interesting multicultural axis that includes Greek tragedy, Aztec mythology and Chicano culture to inscribe on stage her personal vision of a Chicana lesbian Medea/Llorona who is hungry for a new Aztlán” (Fernández Morales 2004: 85). This play is more experimental than the previous one we have examined, and it focuses on the struggle of an individual against the status

\footnotetext{
${ }^{6}$ I have discussed this topic of body politics and transgression in an article entitled "Chicana Voices in U.S. Theater: Gorditas e Ilegales in Josefina López's Real Women Have Curves”, published in the volume About Culture (Elizabeth Woodward Smith, ed. Universidade de Santiago de Compostela, 2004).

7 The Hungry Woman opened in 1995, but was published in 2000. This is the bibliographical reference I will use in my article.
} 
$q u o$, presenting Medea as the clear protagonist of a tragedy that keeps the basic elements of the genre intact, but is re-written from a Chicana perspective. Thus, in Moraga's version the Chorus ${ }^{8}$ becomes a Cihuatateo, a group of warrior women who, according to the Aztec myth, have died at childbirth; Euripides' "barbaric" Medea, who had a suspicious knowledge of herbs and natural remedies, is for Moraga "a midwife and curandera" (Moraga 2000: 295); Jasón is a treacherous husband trying to gain a position in the new nation through marriage to a Native teenager; and the two sons of the classical text blend together in thirteen-year-old Chac-Mool, whose hidden side is revealed when he renames himself "Adolfo" and decides to go back to his father.

Medea's first breach of a barrier in Moraga's play comes, obviously, from her gay condition. Both in Gringolandia and in Aztlán, homosexuality (and particularly, lesbianism), is a negative concept and a reason for expulsion. The symbolic setting that the playwright creates in order to denounce patriarchal compulsory heterosexuality is but a translation of Moraga's real-life environment. Labeled for her race as well as for her sexual option, the author longs for an alternative in and outside the theatrical universe:

Chicana lesbians and gay men do not merely seek inclusion in the Chicano nation; we seek a nation strong enough to embrace the full range of racial diversities, human sexualities, and expressions of gender. We seek a culture than can allow for the natural expression of our femaleness and maleness and our love without prejudice or punishment (Moraga 1993: 164).

Similarly, the protagonist of her play criticizes her conservative context, commenting that "[a] woman is nothing in Aztlán without a husband" (Moraga 2000: 338), and she expresses her fear that Chac-Mool, upon reclaiming his white name, will adopt the repressive ways of patriarchal mainstream culture: "Betrayal occurs when a boy grows into a man and sees his mother as a woman for the first time. A woman. A thing. A creature to be controlled" (340). Futhermore, she denounces the fusion of male chauvinist and homophobic prejudices by challenging Chac-Mool's concept of "normal" in a scene that serves as a summary of the dramatic conflict:

You want normal? Then go with your father. He is perfectly normal. It's normal to send your five-year-old child and his mother into exile and then seven years later come back to collect the kid like a piece of property. It's normal for a nearly sixty-year-old Mexican man to marry a teenager. It's normal to lie about your race, your class, your origins, create a completely unoriginal fiction about yourself and then name yourself la patria's poet. But that's normal for a country who robs land from its daughters to give to its sons unless they turn out to be jotos (343).

Uneasy in this androcentric system, Medea turns to her female ancestors for advice. Moving away from the model of a decent Chicana, she rejects the Virgin of Guadalupe and chooses to side with the ancient goddesses of the Aztec tradition. In this second line of transgression, Medea identifies with Coatlicue, the dual goddess of creation and destruction,

\footnotetext{
8 The Chorus was female in Euripides' version of the myth of Medea (it was a group of Corynthian women), but not in other texts that deal with the infanticidal woman. In Seneca's version, for example, the Chorus was all-male.
} 
mother of the War God ${ }^{9}$. Coatlicue appears in the Prelude, when her altar is seen and we can recognize her by her serpent skirt. Later on, Medea emerges in her guise as "la mera madre diosa" (329), while Luna will be symbolically identified with her daughter Coyolxauhqui and Chac-Mool as her violent son Huitzilopochtli (Prelude to Act Two). Torn between womanly love and motherly loyalty, Medea will end up using the double power of Coatlicue (to give birth and to destroy life), an act that the author explains when she says: "Fundamentally, misogyny is about fear of women's power. Medea doesn't get to live out her creative power, but instead of passively accepting that, she brings out the destructive Coatlicue aspect -she brings out that other side of her which men fear. In society's view, the most anti-female thing you can do is kill your child" (qtd. in Greene 2001: 325).

Condemned as a lesbian by her own husband, deprived of her land and ultimately betrayed by her son, Medea takes what seems to be her only way out, i.e.: (self)destruction. In a 2000 interview, Moraga quotes a partera friend saying explaining that "[i]nfanticide is not a homicide [...] but a suicide. A mother never completely separates from her child. She always remains a part of her children" (qtd. in Oliver-Rotger 2004: 6). By poisoning Chac-Mool, Medea signs her own death sentence and actually dies at the end of the play, taken by the spirit of her son to a place she can finally call home:

CHAC-MOOL: [...] Watch the moon. By the full moon, you'll be looking at saguaros. You're going home.

MEDEA: How will I get there?

CHAC-MOOL: I'm taking you (Moraga 2000: 362).

In the Chicana tradition re-created by Cherríe Moraga, Medea, after killing ChacMool, is related to with another infanticidal mother: La Llorona. A constant ghost-like presence for many Chicano/a boys and girls, La Llorona is said to have killed her children out of spite for her husband, and is condemned to wandering forever, mourning and wailing, “¡aaaaaaay mis hijos!”. Reclaimed as a legendary figure by Chicana authors, Medea-La Llorona in the play echoes yet another mythical reference used by Moraga: The Hungry Woman, who has mouths all over her body and constantly cries for food. Moraga's hungry Medea cries with her whole body on stage: she cries for her lost land, for her lost love, for her lost child... and she warns her peers:

My tragedy will be an example to all women like me. Vain women who only know to be the beloved. Such an example I shall be that no woman will dare to transgress those boundaries again. You, you and your kind, have no choice. You were born to be a lover of women, to grow hands that could transform a woman like those blocks of faceless stone you turn into diosas. I, my kind, is a dying breed of female. I am the last one to make this crossing, the border has closed behind me. There will be no more room for transgressions (Moraga 2000: $322)$.

\footnotetext{
9 Sibylle Gfellner explains the very complex myth of Coatlicue in her article "Personajes míticos femeninos en el escenario" (1999). This article will not develop the myth at length; but will simply deal with the elements that are relevant for Moraga's play.
} 
The Hungry Woman, then, is a tragedy of border-crossing, a tale of transgression and solitary fall of an unusual heroine punished for her mistakes. This has been precisely praised as one of its main strengths as a piece of dramatic literature: "[Moraga's] fascination with boundaries and borders, the illusion of dichotomous identities, is what gives The Hungry Woman a vitality that transcends creeds" (Fowler 2001: 2). On the contrary, Real Women Have Curves is a comedy where transgression becomes the point of union between women with a need to face the system and the two cultures that oppress them. In both plays a systematic negotiation of identities (ethnic and sexual) is to be found, with very different consequences for the diverse choices made. Two styles, two ways of putting the Chicana feminist plight on stage by means of a rich language, powerful, suggestive images and complex polyphony. Two paths, in conclusion, towards a new state of things in which there is a place for every kind of woman, every shape of body and every color of skin; where no green cards are necessary to become a human being.

\section{REFERENCES}

Calvo, J.M. 2004. “El poder latino.” El País Semanal 1457: 30-41.

Cantú, N.E. 2001. Canícula. Snapshots of a Girlhood en la Frontera. Albuquerque: University of New Mexico Press.

Cardoso, P., dir. 2003. Real Women Have Curves. New York: Time Warner Entertainment.

Cisneros, S. 2002. Caramelo. New York: Vintage Books.

Fernández Morales, M. 2004. "Revising La Llorona On Stage: Cherríe Moraga's The Hungry Woman: A Mexican Medea." Perspectivas Transatlánticas en la literatura chicana. Ensayos y creatividad. Eds. M. Herrera-Sobek, F. Lomelí y J.A. Perles Rochel. Málaga: Servicio de Publicaciones de la Universidad de Málaga. 85-95.

Fowler, J. "The Hungry Woman. A Mexican Medea Dines on Questions of Race, Sexuality and Desire.” Dallas Observer. 5 July 2001. <www.dallasobserver.com>.

Gfellner, S. 1999. "Personajes femeninos en el escenario: Malinche, Coatlicue, 'las vírgenes', y 'la madre patria'." Performance, Pathos, Política de los Sexos. Teatro Postcolonial de Autoras Latinoamericanas. Eds. H. AdLeR y K. RöTtGer. Madrid: Vervuert. 195-210.

Greene, A. 2001. Women Who Write Plays. Interviews with American Dramatists. Hanover: Smith and Kraus.

Huerta, J. 2000. Chicano Drama: Performance, Society and Myth. Cambridge: Cambridge University Press.

"Latina Policy Issues.” University of California, Los Angeles. 26 Jan. 2004. <http:// clnet.ucla.edu/challenge/32.htm $>$.

LóPEz, J. 1996. Real Women Have Curves. A Comedy. Woodstock: Dramatic Publishing. 
Moraga, C. 1983. Loving in the War Years. Lo que nunca pasó por sus labios. Cambridge: South End Press. 1993. The Last Generation. Prose and Poetry by Cherríe Moraga. Boston: South End Press. 2000. The Hungry Woman. A Mexican Medea. Out of the Fringe. Contemporary Latina/Latino Theatre and Performance. Eds. C. SvicH and M.T. MARrero. New York: Theatre Communications Group. 292-362.

NARBOna CARrión, M.D. 2004. "La literatura chicana como reflejo de la búsqueda de la identidad: Real Women Have Curves: A Comedy." Perspectivas Transatlánticas en la literatura chicana. Ensayos y creatividad. Eds. M. Herrera-Sober, F. Lomelí y J.A. Perles Rochel. Málaga: Servicio de Publicaciones de la Universidad de Málaga. 223-34.

Oliver-Rotger, M.A. 2004. “An Interview with Cherríe Moraga.” Voices from the Gaps. University of Minnesota. 5 April 2005. <http://voices.cla.umn.edu/newsite/ soundings/ROTGERmaria-moraga.htm>.

Perles Rochel, J.A. 2004. "Introducción.” Perspectivas Transatlánticas en la literatura chicana. Ensayos y creatividad. Eds. M. Herrera-Sober, F. Lomelí y J.A. Perles Rochel. Málaga: Servicio de Publicaciones de la Universidad de Málaga. 11-18.

RAmírez, E. 2000. Chicanas/Latinas in American Theatre: A History of Performance. Bloomington and Indianapolis: Indiana University Press.

Ruiz, V. L. 2000. "From Out of the Shadows: Mexican Women in the United States." OAH Magazine of History. Organization of American Historians. 27 Jan. 2004. <http://www.oah.org/pubs/magazine/Latinos/ruiz.html>.

Saldívar-Hull, S. 2000. Feminism on the Border. Chicana Gender Politics and Literature. Berkeley: University of California Press.

Yarbro-Bejarano, Y. 1996. "Chicana Literature From a Chicana Feminist Perspective." Chicana Creativity and Criticism. New Frontiers in American Literature. Eds. M. Herrera-Sobek \& H.M. Viramontes. Albuquerque: University of New Mexico Press. 213-19. 